\title{
Isolation and Characterization of Phosphate Solubilizing Bacteria from the Rhizosphere of Potato Plant
}

\author{
Deepak Pandey and Chayanika Putatunda*
}

\author{
School of Biotechnology and Biosciences, Lovely Professional University, \\ Jalandhar - Delhi G.T. Road, Phagwara, Punjab-144411, India \\ *Corresponding author
}

\begin{abstract}
A B S T R A C T
Keywords

Phosphate solubilization, Bacteria, Rhizosphere, Enterobacter cancerogenus, Potato

Article Info

Accepted: 10 December 2017 Available Online: 10 January 2018

Phosphorus is important for early shoot and root development, providing energy for plant processes such as ion uptake and transport. Phosphorus is the most important nutrient element (after nitrogen) limiting agricultural production in most regions of the world. Phosphorous is the second major nutrient for the plants, however, it is the least soluble in soil. The total phosphorous in the soil ranges from $0.01-0.2$ per cent but only a small amount of it is available to the plants. In the present study, a total of ten different bacterial isolates were obtained from potato rhizosphere soil collected from different locations. Out of these, Enterobacter cancerogenus D-m-2, having potential to solubilize insoluble inorganic phosphate was characterized. The strains showed diverse levels of phosphate solubilization activity in liquid broth culture in presence of various carbon and nitrogen sources. Enterobacter cancerogenus D-m-2 showed maximum phosphate solubilizing with lactose as carbon source and ammonium oxalate as nitrogen source. The final value of in vitro Phosphate solubilization by the isolate was $8.37 \mu \mathrm{g} / \mathrm{ml}$.
\end{abstract}

\section{Introduction}

Potato is a major crop grown in different parts of the world. According to an estimate the total world potato production was estimated at 364.808.768 tonnes in 2012.The FAO data shows that China is now the biggest potato producer, and almost a third of all potatoes is harvested in China and India (http://www. potatopro.com/world/potato-statistics/).

Farmers cultivate potatoes by using seed potatoes that have been cut in half with at least one eye on each piece. They plant them in rows about 2 to 3 feet apart and 2 to 4 inches deep. After about 90 to 140 days they will dig them up carefully and store in cool temperatures between $50^{\circ}$ to $60^{\circ}$ degrees $\mathrm{F}$ in a dark location (Ensminger et al., 1986).

The crop belongs to the family Solanaceae and was domesticated by pre-Columbian civilizations in the Andean highlands of Peru and Bolivia (Pamela, 2010).It is well known that for biological growth and development of plants Phosphorus acts as one of the major essential macronutrients. About $150 \mathrm{~kg} / \mathrm{ha}$ phosphate chemical fertilizer in inorganic form is the best amount for potato cultivation (Singh et al., 2003). Absence of this element 
in the soil could limit the plant development (Prejambada et al., 2009; Victoria et al., 2009). The use of chemical fertilizers incurs extra burden on the farmers apart from causing environmental problems (Maheswar, 2012).

A number of bacterial species, mostly those associated with the plant rhizosphere, are able to exert a beneficial effect upon plant growth. This group of bacteria has been termed as 'plant growth promoting rhizobacteria' (PGPR) and among them are strains from genera such as Pseudomonas, Serratia, Azospirillum, Burkholderia, Bacillus, Enterobacter, Rhizobium, Erwinia, Alcaligenes, Arthrobacter, Acinetobacter and Flavobacterium (Rodríguez et al., 1999).Many of these microorganisms act as phosphate solubilizing agent and convert the insoluble phosphorus into soluble form $\mathrm{HPO}_{4}{ }^{2-}$ and $\mathrm{H}_{2} \mathrm{PO}_{4}{ }^{-}$by production of acids, exchange reactions, acidification, chelation, and polymeric substance formation (Delvasto et al., 2006). These microorganisms thus reduce the dependence on chemical fertilizers and hence are being regarded as an alternative to the conventional chemical fertilizers.

Several workers have reported the isolation of various phosphate solubilizing bacteria from rhizospheres of a variety of plants. Islam et al., (2006) isolated and purified a total of 30 bacterial strains from the rhizoplane of rice by repeated streak culture on NBA medium. The phosphate solubilization index of the rice isolates varied from 1.2 to 6.7 . The isolate Acinetobacter sp. BR-25 exhibited the highest phosphate solubilization index (6.7) followed by BR-15 (4.8) when calcium phosphate was used as P source. Maheshwar et al., (2012) collected the soil sample from different rhizosphere soil of groundnut and reported the presence of phosphate solubilizing microorganisms. The isolated bacterial strains of Bacillus subtilis and Bacillus cereus, exhibited maximum phosphate solubilization and were found to be active in solubilization of tricalcium phosphate under in-vitro condition. In the present investigation potato rhizosphere soil samples were used to ascertain the presence of phosphate solubilzing bacteria and to check their phosphate solubilization activity under in vitro conditions.

\section{Materials and Methods}

\section{Isolation of Phosphate solubilizing Bacteria}

Rhizosphere soil samples from the potato plant was collected from Phagwara (Punjab), Karnal (Haryana), Dehri on sone (Bihar), Shahjahapur (Uttar Pradesh), and Harda (Madhya Pradesh). Each rhizosphere soil sample was serially diluted and then plated on Pikovskaya medium (Pikovskaya, 1948) plates and incubated at $37^{\circ} \mathrm{C}$ for $72 \mathrm{hrs}$. The composition of Pikovskaya's medium was as follows $(\mathrm{g} / \mathrm{L})$ : Glucose- 10, Tricalcium Phosphate- 5, Ammonium sulphate- 0.5, sodium chloride- 0.2, Magnesium sulphate0.1 , Potassium chloride- 0.2 , yeast extract0.5, Manganous sulphate- 0.002, Ferrous sulphate- 0.002. The bacterial isolates obtained were purified by streaking on fresh Pikovskaya's media and purified isolates were transferred on to slants and stored in refrigerated conditions at $4{ }^{\circ} \mathrm{C}$ (Saini et al., 2015).

\section{Screening}

\section{Primary screening}

The bacterial isolates were spotted on Pikovskaya agar medium and the zone of phosphate solubilization was measured. The Phosphate solubilization efficiency (PSE) was calculated using the formula PSE $(\%)=(\mathrm{Z}$ C)/C X 100, where $Z=$ zone of phosphate solubilization, $\mathrm{C}=$ colony radius (Kundu et al., 2009). 


\section{Secondary screening}

Isolates were transferred from a slant into 10 $\mathrm{ml}$ nutrient broth and incubated overnight. One $\mathrm{ml}$ of this inoculum (A=0.5 at) was added in Pikovskaya (PKV) broth and incubated at $37^{\circ} \mathrm{C}$. After incubation, the cultures were centrifuged and the quantity of Phosphorus in the supernatant was assessed by Johns method (John, 1970).

\section{Characterization of selected isolates}

The selected bacterial isolate was characterized on the basis of morphology and biochemical characteristics as per Bergey's manual of systematic bacteriology (Holt, 1994) and identified on the basis 16srDNA sequence. The sequencing was carried out by Samved Biotech, Ahmedabad, India.

\section{Results and Discussion}

Potato rhizosphere soil sample were collected from the Phagwara (Punjab), Karnal (Haryana), Dehri on sone (Bihar), Shahjahapur (Uttar Pradesh), and Harda (Madhya Pradesh).A total of ten different types of bacterial isolates were obtained from the potato rhizosphere soil sample collected. A total of ten different types of bacterial isolates were obtained from the potato rhizosphere soil sample collected. The isolates obtained from Punjab state were named D.p-1 to D.p-2. Similarly the isolates obtained from soil sample collected from Karnal, (Haryana) were named D.h-1 to D.h-2. The bacterial isolates obtained from soil sample collected from Dehri on sone, (Bihar) were designated as isolate D.b-1 to D.b-2. Sample from the Shahjahapur, (Uttar Pradesh) soil sample, two isolates were obtained which were named as D.u-1 to D.u-2. From the soil sample collected from Harda, (Madhya Pradesh) named D.m-1 to D.m-2. The bacterial isolates were showing different colony morphologies for e.g. medium sized round white colored colonies were formed by D. m-1 while D. u- 1 showed small round creamish colonies. The isolate named as D.b-1 was showing small round yellowish colored colonies while the isolate D.b-2 showed small round pink color colony.

\section{Screening of phosphate solubilising activity}

All the bacterial isolates were subjected to screening by plate assay method, where they were spotted on Pikovskaya's medium plates and incubated for 5 days and the PSE (\%) was calculated on the basis of zone of Phosphate solubilzation. It was observed that the isolate D.m-1 showed maximum PSE of $346 \%$. However in the case of isolates D.h-2, D.u-1, D.b-1, D.b-2 and D.m-2, no zone of phosphate solubilization was formed. The rest of the isolates showed the PSE in the range of 103 to $283 \%$. Similar kinds of results have also been obtained by several workers (Kundu et al., 2009; Gupta et al., 2007). Israr and Singh (2014) also used similar technique and reported that out of the 57 isolates obtained from rhizosphere of banana, 30 isolates showed clear zones of phosphate solubilization and were regarded as potential phosphate solubilizers by the workers. Maheswar et al., (2012) used rhizosphere of groundnut for solubilization of phosphate whereas Islam et al., (2006) used rice (Oryza sativa L.) for isolation and identification of potential phosphate solubilizing bacteria.

The bacterial isolates were then subjected to secondary screening by assessing their phosphate solubilizing activity under liquid culture conditions. Out of the 10 isolates D.m2 showed maximum Phosphate solubilizing efficiency $(6.35 \mu \mathrm{g} / \mathrm{ml})$ after $48 \quad \mathrm{hrs}$ of incubation and hence was selected for further optimization. However, no direct co-relation between the primary and secondary screening was observed, as D-m-2 did not produce any zone of phosphate solubilization although, it 
was showing highest activity during secondary screening. Also, in case of D-p-1, a PSE of $277 \%$ was observed during primary screening. However, its activity during secondary screening was found to be only 1.32 $\mu \mathrm{g} / \mathrm{ml}$. Similar variations have also been reported by other workers (Narveer et al., 2014; Saini et al., 2015).

\section{Optimization of conditions}

Various factors like incubation period 24 to 96 h), pH (4 to 9), Carbon source (Dextrose, Starch, Sucrose and Lactose), Nitrogen source (Ammonium Sulphate, Ammonium Chloride, Ammonium nitrate and Ammonium oxalate) were assessed for determining their effects on the phosphate solubilization efficiency of selected isolates by varying one parameter at a time.
$\mathrm{pH}$ is one of the crucial factors impacting the growth and activity of microorganisms. In the present case, the isolate D.m-2 was observed to show maximum Phosphate solubilizing efficiency $(6.70 \pm 0.07638)$ at the $\mathrm{pH} 5$ whereas least Phosphate solubilizing efficiency $(5.67 \pm 0.05859)$ was shown at basic $\mathrm{pH}$ i.e. 9 (Fig. 1). Some other workers like Sahu and Jana (2007) have also found acidic $\mathrm{pH}$ to result into good phosphate solubilisation activity.

However, Yu et al., (2011) and Xiang et al.,, (2011) have reported pH 7 to be optimum for phosphate solubilisation by actinomycetes isolated from Vellar estuary sediment samples. Several other workers have reported a range of pH 6 to 8 for phosphate solubilization (Naik et al., 1982; Promod and Dhevendaran, 1987; Seshadri et al., 2002).

Table.1 Phosphate solubilizing efficiency $(\mu \mathrm{g} / \mathrm{ml})$ of various isolates in Pikovskaya broth

\begin{tabular}{|c|c|}
\hline Isolate & Phosphate solubilizing efficiency $(\mu \mathrm{g} / \mathrm{ml})$ \\
\hline D.p-1. & 1.32 \\
\hline D.p-2. & 5.67 \\
\hline D.h-1. & 3.49 \\
\hline D.h-2. & 4.22 \\
\hline D.u-1. & 2.85 \\
\hline D.u-2. & 4.01 \\
\hline D.b-1. & 2.39 \\
\hline D.b-2. & 0.92 \\
\hline D.m-1. & 1.15 \\
\hline D.m-2. & 6.35 \\
\hline
\end{tabular}

Table.2 Morphological and biochemical characteristics of the isolate D.m-2

\begin{tabular}{|c|c|c|}
\hline Serial no. & Characteristic test & Result \\
\hline 1. & Colony morphology & Medium size Creamish color colony \\
\hline 2. & Cell shape & Rod shaped \\
\hline 3. & Gram stain & Negative \\
\hline 4. & Endospore & No spore formed \\
\hline 5. & Indole & Negative \\
\hline 6. & Methyl red & Negative \\
\hline 7. & Voges-Proskauer & Positive \\
\hline 8. & Citrate utilization & Positive \\
\hline 9. & Catalase & Positive \\
\hline
\end{tabular}


Fig.1 Effect of $\mathrm{pH}$ on phosphate solubilizing efficiency $(\mu \mathrm{g} / \mathrm{ml})$ of isolate D.m-2

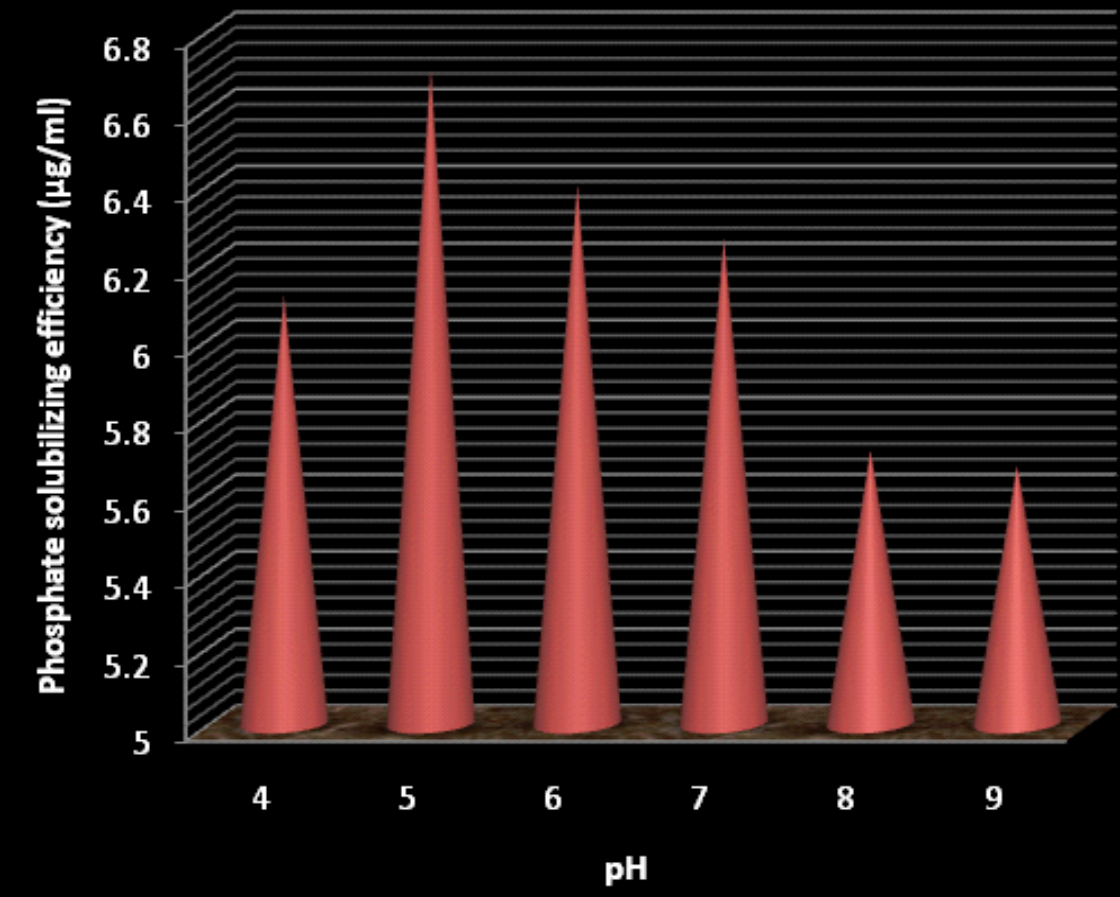

m Phosphate solubilizing efficiency $(\mu \mathrm{g} / \mathrm{ml})$

Fig.2 Effect of carbon source on phosphate solubilizing efficiency $(\mu \mathrm{g} / \mathrm{ml})$ of isolates D.m-2

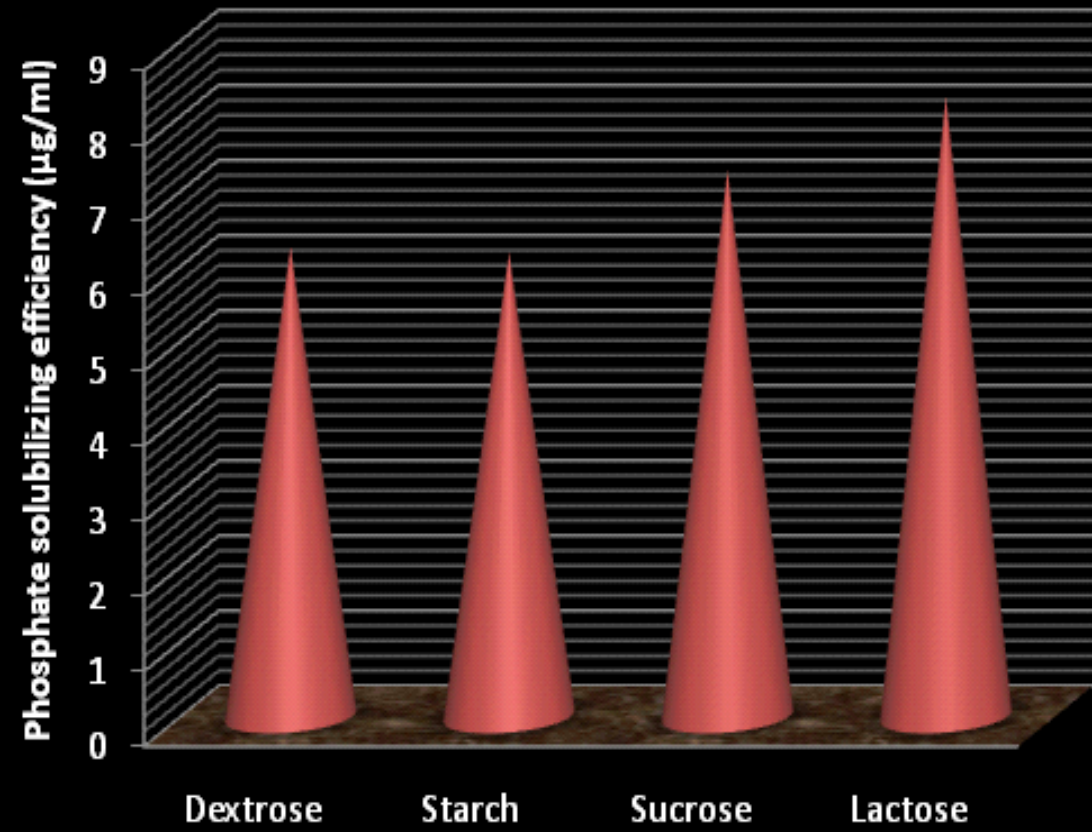

ت Phosphate solubilizing efficiency $(\mu \mathrm{g} / \mathrm{ml})$

Carbon Source 
Fig.3 Effect of nitrogen source on Phosphate solubilizing efficiency $(\mu \mathrm{g} / \mathrm{ml})$ of isolates D.m-2
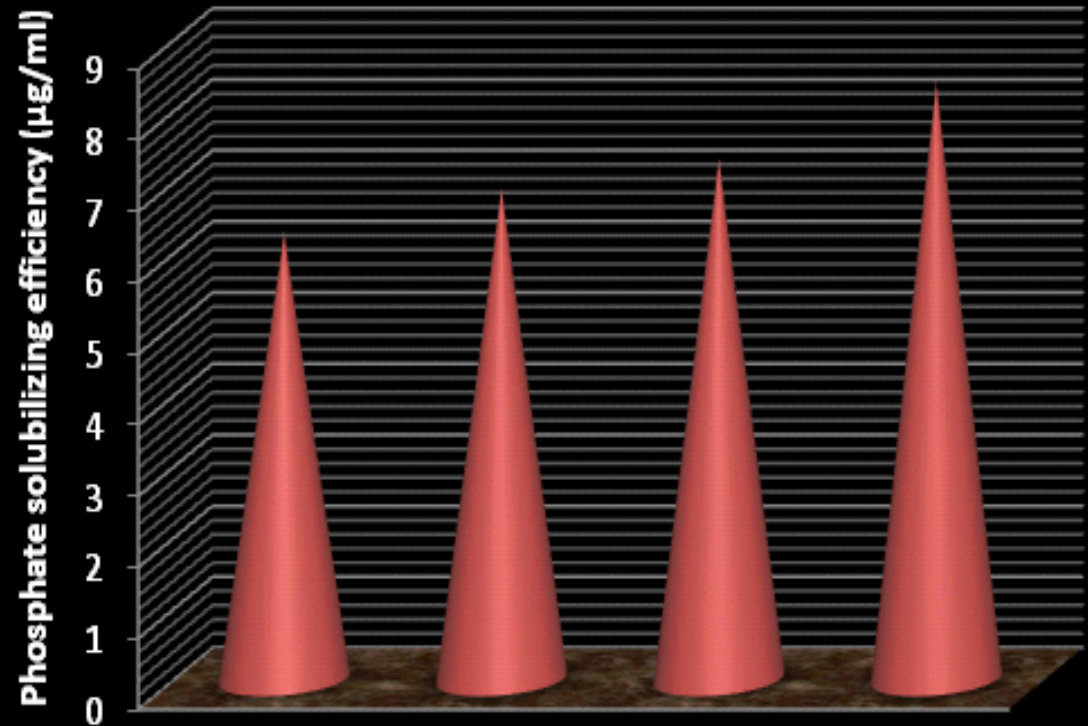

ت Phosphate solubilizing efficiency $(\mu \mathrm{g} / \mathrm{ml})$

Ammonium Ammonium Ammonium Ammonium

sulphate chloride nitrate oxalate

Nitrogen source

Fig.4 Effect of shaking and nonshaking on phosphate solubilizing efficiency $(\mu \mathrm{g} / \mathrm{ml})$ of isolates D.m-2

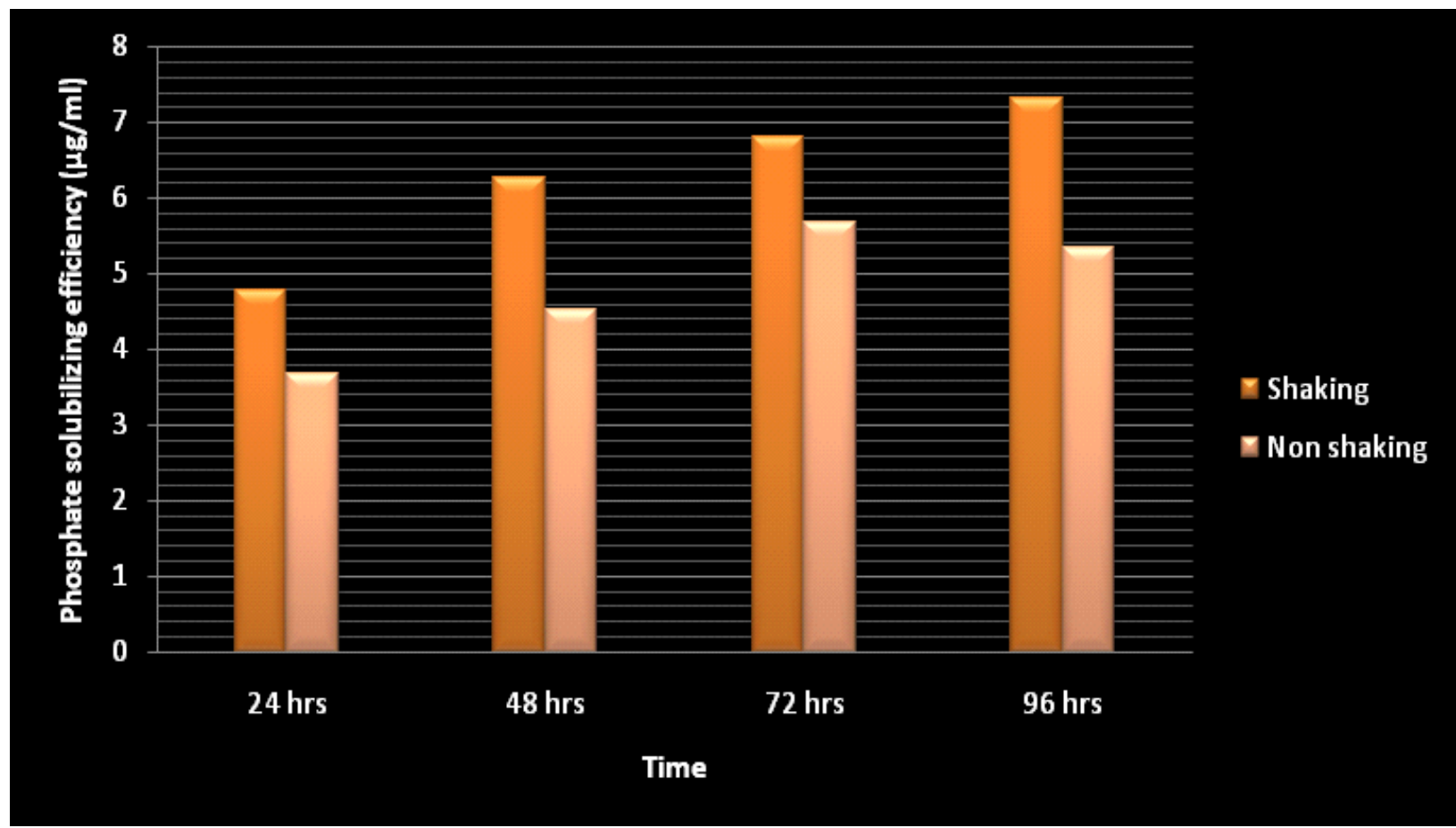


Lactose proved to be the best carbon source for the phosphate solubilization (8.27 \pm 0.02563 ) of isolate in the PKV broth, whereas starch supported lesser phosphate solubilization (6.18 \pm 0.18511$)$ (Fig. 2). Other two sources dextrose and sucrose resulted in medium activity. As per Kumari and Gupta (2013) Pseudomonas lurida showed maximum solubilization of Tri-Calcium Phosphate with glucose followed by maltose $>$ galactose $>$ sucrose $>$ xylose. Narsian and Patel et al., (2000) observed maximum $\mathrm{P}$ solubilization by with arabinose and glucose as the carbon source in case of Aspergillus aculeatus. Maheswar et al., (2012) reported that in case of bacterial isolates, the incorporation of glucose followed by lactose increased solubilization of phosphate and enhanced acid production efficiently.

Amongst the various nitrogen sources Ammonium oxalate resulted in maximum Phosphate solubilizing efficiency (8.40 \pm 0.05108) whereas ammonium sulphate showed least Phosphate solubilizing efficiency (6.26 \pm 0.08888) (Fig. 3). Ammonium chloride and ammonium nitrate also resulted in less phosphate solubilizing activity as compared to ammonium oxalate. Several workers (Illmer and Schinner, 1992; Lapeyrie et al., 1991) have reported that a significant number of bacteria have been found of being capable to solubilizing phosphate only in the presence of ammonium as the nitrogen source.

On assessing the phosphate solubilizing activity of the isolate under shaking and stationary conditions, it was observed that higher activity was there in the former as compared to the latter (Fig. 4). This could be because of the fact that microbes might be getting better aeration and nutrition due to the agitation. Also, the incubation period was assessed and it was found that in case of stationary conditions the maximum activity was found after 72 hours (5.69 \pm 0.05859$)$, while in shaking conditions, an incubation of 96 hours resulted in highest phosphate solubilization $(7.32 \pm 0.11136)$. Banerjee et al., (2010) have also reported that in case of TRSB16the phosphate solubilizing activity was highest on the fourth day (96 hours).

\section{Characterization and identification of selected isolate}

The selected isolate D-m-2 was found to be gram negative, rod shaped, non-spore forming, Indole production negative, MR negative, VP positive, citrate utilization positive and catalase positive (Table- 2). The microorganism was also subjected to 16srDNA sequencing and was found to showing 99\% similarity with Enterobacter cancerogenus. The sequence is deposited in the NCBI under accession number HQ242733. 1.

The present investigation was carried out with the aim of isolation and characterization of Phosphate solubilizing bacteria from rhizosphere soil of potato plant from the Phagwara (Punjab), Karnal (Haryana), Dehri on sone (Bihar), Shahjahapur (Uttar Pradesh) and Harda (Madhya Pradesh). A total of 10 phosphate solubilising bacterial isolates were obtained from the samples. The isolates showed diverse levels of phosphate solubilization activity during primary and secondary screening and the isolate D-m-2 which showed the highest activity during secondary screening was selected for subsequent studies. On optimization of culture conditions, the isolate was D-m-2 showed maximum phosphate solubilizing with lactose as carbon source and ammonium oxalate as nitrogen source in $96 \mathrm{hrs}$. The isolate was characterized and identified on the basis of 16s rDNA sequence and was found to be showing 99\% similarity with Enterobacter cancerogenus. The selected isolate D-m-2 
was found to be gram negative, rod shaped, non-spore forming, Indole production negative, MR negative, VP positive, citrate utilization positive and catalase positive. Thus, the isolate may prove to be potential candidates for being used as bio fertilizers.

\section{References}

Banerjee, S., Palit, R., Standing, D and Sengupta, C. 2010. Stress induced phosphate solubilization by Arthrobacter sp. and Bacillus sp. isolated from tomato rhizosphere Aus. J. Crop Sci. 4(6): 378-383.

Delvasto, P., Valverde, A., Ballester, A., Muñoz, J.A., González, F., Blázquez, M.L., Igual, J.M., and García-Balboa, C 2008. Diversity and activity of phosphate bioleaching bacteria from a high-phosphorus iron ore. Hydrometallurgy. 92: 124-129.

Ensminger, L. B., Andres, J. A., Papa, M. F. D., Pistorio, M., and Rosas, S. B. 1986. Response of alfalfa (Medicago sativa L.) to single and mixed inoculation with phosphate-solubilizing bacteriaand Sinorhizobium meliloti. Biol Fertil Soils.46:185-190.

Gupta, N., Sabat, J., Parida, R., and Kerkatta, D. 2007. Solubilization of tricalcium phosphate and rock phosphate by microbes isolated from chromite, iron and manganese mines. Acta Bot. Croat, 66(2): 197-204.

Holt, T. 1994. Bergey's Manual of Systematic Bacteriology Int. J. of Syst. Bact, 408

Illmer, P. and Schinner, F. 1992. Solubilization of inorganic phosphates by microorganisms isolated from forest soil. Soil Biol Biochem, 24: 389-395.

Islam, T., Deora, A., Hashidoko., Y., Rahman., A., Ito., $\mathrm{T}$ and Tahara, $\mathrm{S}$. 2006. 16S rRNA genes sequencing data as Acinetobacter sp. BR-12, Klebsiella sp. BR-15, Acinetobacter sp.BR-25,
Enterobacter sp. BR-26, Microbacterium sp. BRS-1 and Pseudomonas sp. BRS-2 showed varying levels of phosphate solubilizing activity in both agar plate and broth assays. Z. Naturforsch. 62c, 103-110.

Israr, B. and Singh, J. 2014. Phosphorus availability with alkaline/ calcareous soil., Western Nutrient Management conference, Salt Lake City, 6:88-93.

John, M. K. 1970. Colorimetric determination of phosphorus in plant materials and soil as well as ascorbic acid. Soil Sci. 109:214-220.

Kundu, B.S., Nehra, K., Yadav, R. and Tomar, M. 2009. Plant growth promoting abilities of phosphate solubilizers from the rhizosphere of Parthenium hysterophorus soil. Ind. J Microbiol, 49:120-127.

Lapeyrie, F., Ranger J., and Vairelles, D. 1991. Phosphate solubilising activity of ectomycorrhizal fungi in vitro. Can. J. Bot. 69: 342- 346.

Maheswar, N., and Sathiyavani, G. 2012. Quantitative analysis of organic acid produced by phosphate solubilizing Bacteria. Journal of Chemical and Pharmaceutical Research, 4(8):40074011

Naik, S., Panneerselvam, T., and Sivakumar, T. 1982. Evaluation of Indole-3-Acetic Acid in phosphate solubilizing microbes isolated from Rhizosphere of soil. Inter. J. Curr. Microbiol. App. Sci. 2:29-36.

Narsian, R., and Patel, G. 2000. Efficiency of Tricalcium Phosphate Solubilization by Two Different Endophytic Penicillium Sp. Isolated from Tea (Camellia sinensis L.). Euro. J. Exp. Bio. 2:13541358.

Narveer., Vyas, A., Kumar, H., and Putatunda, C. 2014. In vitro Phosphate Solubilization by Bacillus sp. NPSBS 3.2.2 obtained from the Cotton Plant 
Rhizosphere Biosci. Biotech. Res Asia, 11(2): 401-406.

Pamela, Y.S. 2010. Potato (Solanum tuberosum) was domesticated by preColumbian civilizations in the Andean highlands of Peru and Bolivia. Indian $\mathbf{J}$ Agric Sci. 80:329-332.

Pikovskaya R.I. 1948. Mobilization of phosphorus in soil in connection with vital activity of some microbial species. Microbiologiya, 17:362-370.

Prejambda, I. D., Widada, J., Kibirun, C., and Widianto, D., 2009. Secretion of Organic Acids by Phosphate Solubilizing Bacteria Isolated from Oxisols. J. Tanah Trop. 14(3): 245-25

Promod, K., and Dhevendaran, V. 1987. Phosphate solubilizing bacteria isolated from the rhizosphere soil and its growth promotion on black pepper (Piper nigrum L.) cuttings. Springer, First International Meeting on Microbial Phosphate Solubilisation, pp. 325-331.

Rodriguez, H., and Fraga, R. 2009. Phosphate solubilizing bacteria and their role in plant growth promotion. Biotechnol. Adv., 17: 319-339.

Rodriguez, H., and Fraga, R. 1999. The use of phosphate solubilizing bacteria as inoculants simultaneously increases $\mathrm{P}$ uptake by the plant and crop yield. Biotechnol. Adv. 17: 319-339

Sahu, S.N. and Jana, B.B. 2007. Enhancement of the fertilizer value of rock phosphate engineered through phosphatesolubilizing bacteria. Eco Engin. 15: 2739.

Saini, K., Vyas, A., and Putatunda, C. 2015. In vitro phosphate solubilization by maize rhizosphere bacteria. Res. J. Pharma., Bio. Chem. Sci. 6(4): 897-902.

Singh, H., and Negi, V. 2003. Isolation and Characterization of Phosphate Solubilising Bacteria from Rhizospheric Soil Samples. Online Inter. Res. J. 2:2839.

Victoria, D. E., Reyes L. L. and Benitez, A. D. L. C. 2009. Use of $16 \mathrm{~S}$ ribosomal gene for characterization of phosphate solubilizing bacteria associated with corn. Rev. Fitotec. Mex. 32(1): 31-37.

Xiang, W., Liang, H., Liu, S., Luo, F., Tang, J., Li, M., and Che, Z. 2011. Isolation and performance evaluation of halotolerant phosphate solubilizing bacteria from the rhizospheric soils of historic Dagong Brine Well in China. World J. Microbiol. Biotechnol. 27:2629-2637.

Yu, X., Liu, X., Zhu, T. H., Liu, G. H. and Mao, C. 2011. Isolation and characterization of phosphatesolubilizing bacteria from walnut and their effect on growth and phosphorus mobilization. Biol. Fertil. Soils. 47:437446.

\section{How to cite this article:}

Deepak Pandey and Chayanika Putatunda. 2018. Isolation and Characterization of Phosphate Solubilizing Bacteria from the Rhizosphere of Potato Plant. Int.J.Curr.Microbiol.App.Sci. 7(01): 967-975. doi: https://doi.org/10.20546/ijcmas.2018.701.116 